\title{
Visible photoluminescence of polyoxoniobates in aqueous solution and their high electrocatalytic activities for water oxidation
}

\author{
Yichen Ye, Congcong Chen, Hui Feng", Jin Zhou, Juanjuan Ma, Jianrong Chen, Junhua Yuan, \\ Lichun Kong, Zhaosheng Qian" \\ College of Chemistry and Life Science, Zhejiang Normal University, Jinhua, China \\ Email: ${ }^{*}$ fenghui@zjnu.cn, ${ }^{*}$ qianzhaosheng@zjnu.cn
}

Received 13 April 2013; revised 15 May 2013; accepted 28 May 2013

Copyright (C) 2013 Yichen Ye et al. This is an open access article distributed under the Creative Commons Attribution License, which permits unrestricted use, distribution, and reproduction in any medium, provided the original work is properly cited.

\begin{abstract}
The photoluminescence of four polyoxoniobates $\left[\mathrm{Nb}_{6} \mathrm{O}_{19}\right]^{8-},\left[\mathrm{Nb}_{10} \mathrm{O}_{28}\right]^{6-},\left[\mathrm{Ti}_{2} \mathrm{Nb}_{8} \mathrm{O}_{28}\right]^{8-}$ and $\left[\mathrm{H}_{2} \mathrm{Si}_{4} \mathrm{Nb}_{16} \mathrm{O}_{56}\right]^{14-}$ was observed, and its origin was revealed in the view of molecular orbital by means of the computational method. The photoluminescence is originated from singlet transitions, and the calculated values agree well with the experimental data. The results indicate that the size of clusters and the foreigner atoms can affect the fluorescent properties of PONbs. The absorption and emission of these PONbs are originated molecular orbitals contributed mainly by $\mu_{2}-\mathrm{O}$ and $\mathrm{Nb}$ atoms according to $\mathrm{NBO}$ analysis. These PONbs were also found as electrochemical catalysts with high performance for water oxidation, which can effectively split water into oxygen under basic condition with a high catalytic current, and $\mathrm{pH}$ values have remarkable influence on the electrocatalytic activities of these PONbs for water oxidation.
\end{abstract}

Keywords: PONbs; Photoluminescence; NBO Analysis; Electrocatalysis; Water Oxidation

\section{INTRODUCTION}

Polyoxoniobates (PONbs) have attracted significant interest for their fascinating properties and manifold potential applications in many fields such as photocatalytic water dissociation, medicine and radionuclide sequestration, as well as geochemistry [1-4]. Recent review has presented the progress of PONbs chemistry in the preparation and characterization of novel polyniobate compounds [5]. Furthermore, the PONbs family has also been successfully used as model complexes to explore

${ }^{*}$ Corresponding authors. oxygen exchange dynamics for understanding aqueous reactions involving minerals and extended structures and dissolution of similar catalysts [6]. However, little attention has been paid on the optical and catalytic properties of the PONbs.

The hexaniobate $\left[\mathrm{Nb}_{6} \mathrm{O}_{19}\right]^{8-}$ Lindqvist ion is the first $\mathrm{PONb}$, and has been used as an important precursor to prepare large isopolyoxoniobates such as $\left[\mathrm{Nb}_{10} \mathrm{O}_{28}\right]^{6-}$, $\left[\mathrm{Nb}_{20} \mathrm{O}_{54}\right]^{8-}$ and $\left[\mathrm{Nb}_{24} \mathrm{O}_{72} \mathrm{H}_{9}\right]^{15-}$ [7-10]. Some other elements including $\mathrm{Si}, \mathrm{Ge}, \mathrm{P}$ and $\mathrm{Ti}$ were introduced to produce heteropolyoxoniobates in order to tailor the properties of niobate family [11-16]. The incorporation of transition metals into PONbs is able to control their solubility in alkaline solution. Several PONbs were selected to explore their oxygen exchange pathways and reaction activities since they can provide a molecular view of oxide dissolution and are accessible to both experimental approach and theoretical simulation. Oxygen-exchange rates were measured between sites in the Lindqvist ion $\left[\mathrm{Nb}_{6} \mathrm{O}_{19}\right]^{8-}$ and aqueous solution, and metastable polymorphs of the hexaniobate structure were proposed [17]. Reaction dynamics of the larger decaniobate ion $\left[\mathrm{Nb}_{10} \mathrm{O}_{28}\right]^{6-}$ revealed the possible mechanism for the base-promoted dissociation of the decaniobate ion, [18] and the comparison of two isostructrual polyoxoanions $\left[\mathrm{Nb}_{10} \mathrm{O}_{28}\right]^{6-}$ and $\left[\mathrm{Ti}_{2} \mathrm{Nb}_{8} \mathrm{O}_{28}\right]^{8-}$ showed a profound difference in oxygen exchange rate [19]. Recently, a more complex ion $\left[\mathrm{H}_{2} \mathrm{Si}_{4} \mathrm{Nb}_{16} \mathrm{O}_{54}\right]^{14-}$ resembling colloidal oxides and minerals were explored by ${ }^{17} \mathrm{O}-\mathrm{NMR}$ and computational approach [20]. In addition, $\left[\mathrm{Nb}_{10} \mathrm{O}_{28}\right]^{6-}$ as a model example of direct measurement of the formation of ion pairs in solution revealed remarkable similarity between solution and solid-state contact [21]. In spite of these progresses, these PONbs have not been found unique characteristics on redox chemistry, optical response or catalysis up to date. 
Distinctly different reactivity of $\left[\mathrm{Nb}_{6} \mathrm{O}_{19}\right]^{8-}$ and $\left[\mathrm{Nb}_{10} \mathrm{O}_{28}\right]^{6-}$ with hydrogen peroxide was revealed, and the results showed the terminal niobium-bound oxygen atoms can be easily replaced by peroxy groups, implying the possible use of niobates as water-splitting catalysts [22]. Photoluminescence of amorphous niobium oxide was reported [23], and the unique visible luminescence of aluminum polyoxocations was found recently [24]. These results motivated us to explore the photoluminescence properties and electrocatalytic behaviour of decomposing water of these PONbs. In this work, we reported novel photoluminescence properties and high electrocatalytic activities for water oxidation of four PONbs including $\left[\mathrm{Nb}_{6} \mathrm{O}_{19}\right]^{8-},\left[\mathrm{Nb}_{10} \mathrm{O}_{28}\right]^{6-},\left[\mathrm{Ti}_{2} \mathrm{Nb}_{8} \mathrm{O}_{28}\right]^{8-}$ and $\left[\mathrm{H}_{2} \mathrm{Si}_{4} \mathrm{Nb}_{16} \mathrm{O}_{56}\right]^{14-}$. These PONbs can exhibit relatively strong visible blue light, and the photoluminescence mechanism of these PONbs was revealed by means of theoretical approach. These PONbs were also found to efficiently split water to oxygen under basic condition, and there is no remarkable difference in electrocatatlytic activities between isoPONbs and heteroPONbs.

\section{EXPERIMENTAL}

\subsection{Preparation of These PONbs}

The synthesis of the four PONbs was according to the literature methods [7-16,20]. a) Preparation of $\mathrm{K}_{7} \mathrm{HNb}_{6} \mathrm{O}_{19}$. $5 \mathrm{~g} \mathrm{KOH}$ in a $\mathrm{Ni}$ crucible over a bunsen burner was melt and then $1.5 \mathrm{~g} \mathrm{Nb}_{2} \mathrm{O}_{5}$ was very gently added in small portions. When all $\mathrm{Nb}_{2} \mathrm{O}_{5}$ has been added, the mixture was heated for 15 minutes before letting it cool. The solid melt was dissolved in $20 \mathrm{ml}$ of water and then filtered to remove any solids. The crystals, $\mathrm{K}_{7} \mathrm{HNb}_{6} \mathrm{O}_{19}$, grew when put in freezer overnight. b) Preparation of $\mathrm{K}_{6}\left[\mathrm{Nb}_{10} \mathrm{O}_{28}\right]$. The $\mathrm{K}_{7} \mathrm{HNb}_{6} \mathrm{O}_{19}$ crystals were dissolved in a minimum amount of water. Glacial acetic acid was gently added until the $\mathrm{pH}$ is below 6 . The amorphous white precipitate on a cellulose filter was collected and washed repeatedly until the eluent is neutral. The solids on the frit were dried to remove as much trapped water as possible. The powder is hydrous niobium oxide, also known as niobic acid, which was the precursor for the synthesis of $\mathrm{K}_{6}\left[\mathrm{Nb}_{10} \mathrm{O}_{28}\right]$ and $\mathrm{K}_{8}\left[\mathrm{Ti}_{2} \mathrm{Nb}_{8} \mathrm{O}_{28}\right]$.

$\mathrm{Nb}_{2} \mathrm{O}_{5} \cdot \mathrm{nH}_{2} \mathrm{O}(1.00 \mathrm{~g}, 2.1 \mathrm{mmol}$; water $43 \% \mathrm{w} / \mathrm{w})$ was mixed with a solution of $\mathrm{KOH}(3.3 \mathrm{mmol})$ in water $(10$ $\mathrm{mL}$ ). The mixture was heated to $120^{\circ} \mathrm{C}$ in a Teflon-lined Parr vessel for $18 \mathrm{~h}$, and then it is allowed to cool to room temperature. Supernatant by filtration becomes white and opaque on drying. c) Preparation of

$\mathrm{K}_{8}\left[\mathrm{Ti}_{2} \mathrm{Nb}_{8} \mathrm{O}_{28}\right] . \mathrm{Nb}_{2} \mathrm{O}_{5}(0.35 \mathrm{~g}, 2.6 \mathrm{mmol} \mathrm{Nb})$ and titanium isopropoxide $(0.25 \mathrm{~g}, 0.88 \mathrm{mmol})$ were added in an $8 \mathrm{~mL} \mathrm{KOH}$ solution $(0.34 \mathrm{M})$ in a $20 \mathrm{~mL}$ Teflon-lined Parr pressure vessel and stirred for approximately $20 \mathrm{~min}$.
The closed vessel was placed in an oven at $200^{\circ} \mathrm{C}$ for 20 h. The products was the solution of $\mathrm{K}_{8}\left[\mathrm{~K}_{8} \mathrm{Ti}_{2} \mathrm{O}_{28}\right]$. d) Preparation of $\left[\mathrm{K}_{14} \mathrm{H}_{2} \mathrm{Si}_{4} \mathrm{Nb}_{16} \mathrm{O}_{56}\right] \cdot \mathrm{Nb}_{2} \mathrm{O}_{5}(150 \mathrm{mg})$, tetraethyl orthosilicate $(160 \mathrm{mg})$, and potassium hydroxide $(110 \mathrm{mg})$ were mixed with $6 \mathrm{~mL}$ of water in a Teflonlined Parr vessel. The vessel was then placed in a $200^{\circ} \mathrm{C}$ oven for two days.

\subsection{Characterization of These PONbs}

The prepared PONbs were firstly ${ }^{17} \mathrm{O}$-enriched by dissolving in ${ }^{17} \mathrm{O}$-enriched water $(10 \%-15 \%)$ and then standing night, and finally the ${ }^{17} \mathrm{O}-\mathrm{NMR}$ spectroscopy was carried out on Bruker $400 \mathrm{MHz}$ spectrometer to verify the structure of these PONbs. All the characteristic ${ }^{17} \mathrm{O}$ NMR signals were found for the four PONbs except their inert core oxygen atoms by oxygen-exchange with ${ }^{17} \mathrm{O}$-enriched water, and corresponded to the data reported in the literature. The fluorescence spectra and lifetimes of these PONbs were preformed on a FLS 920 spectrophotometer, and their quantum yields were determined using quinine sulphate as the standard, whose quantum yield is 0.577 . Determination of the quantum yields of these oxidized products was accomplished by comparison of the wavelength integrated intensity of these oxidized products to that of the standard quinine sulfate. The optical density is kept below 0.05 to avoid inner filter effects. The quantum yields of these oxidized products were calculated using

$$
\Phi=\Phi_{S}\left[\left(I \cdot A_{S} \cdot n^{2}\right) /\left(I_{S} \cdot A \cdot n_{s}^{2}\right)\right]
$$

The $\Phi$ is the quantum yield, $I$ is the integrated intensity, $A$ is the optical density and $\mathrm{n}$ is the refractive index of the solvent. The subscript $S$ refers to the standard reference of known quantum yield. In this work, when determining PONbs, quinine sulfate was chosen as the standard, whose quantum yield is 0.577 for excitation wavelengths from $200 \mathrm{~nm}$ to $400 \mathrm{~nm}$.

\subsection{The Electrocatalytic Experiment of PONbs for Water Oxidation}

During the electrocatalysis experiment, a $15 \mathrm{~mL}$ glass electrochemical cell containing a glassy Platinum disk working electrode ( $3 \mathrm{~mm}$ in diameter) embedded in Teflon, a platinum wire counter electrode $(1 \mathrm{~mm}$ in diameter, $5 \mathrm{~cm}$ in length) and a saturated calomel electrode as the reference electrode was used. This three-electrode setup was configured with $\mathrm{CHI} 660 \mathrm{C}$ interfaced to a personal computer at room temperature for the electrochemical investigation of these PONbs for water oxidation. The electrolytic solution was bubbled with nitrogen for 15 minutes before the electrochemical experiment to remove oxygen. Homogeneity test of electrode surface from dilute $\left[\mathrm{Nb}_{6} \mathrm{O}_{19}\right]^{8-}$ solutions was conducted by firstly 
scanning the CVs for several cycles with Platinum disk electrode in the blank solution, and then getting the CVs in the $\left[\mathrm{Nb}_{6} \mathrm{O}_{19}\right]^{8-}$ solution, and finally repeating it in the blank solution after washing the Platinum disk electrode. The dependence of current on the concentration of $\left[\mathrm{Nb}_{6} \mathrm{O}_{19}\right]^{8-}$ was carried out using a series of $\left[\mathrm{Nb}_{6} \mathrm{O}_{19}\right]^{8-}$ solutions with different concentrations at the same electrochemical procedure. The influence of $\mathrm{pH}$ value on the electrochemical behavior was performed using $\left[\mathrm{Nb}_{6} \mathrm{O}_{19}\right]^{8-}$ solutions with different $\mathrm{pH}$ value.

\subsection{Computational Details}

The structures of these PONbs were firstly reproduced from their crystal structure and then optimized using DFT method with the B3LYP functional. The basis set LanL2DZ was performed for $\mathrm{Nb}$ and $\mathrm{Ti}$, and $6-31+\mathrm{G}(\mathrm{d}, \mathrm{p})$ was used for the other elements $[25,26]$. The vibrational frequency was carried out to verify the stable structure. Solvent effects were evaluated by means of the integral equation formulation of the polarisable continuum model (IEFPCM) for all the calculations [27]. The electronic transition energies, oscillator strengths and excited-state compositions were computed by the time-dependent density functional theory method (TD-DFT) with B3LYP functional at the same basis sets $[28,29]$. The optimization of electronic transition structure and emission energies was also computed by TD-DFT method [30-32]. NBO analysis was also performed to obtain the molecular orbital [33]. All the calculations were carried out with the Gaussian 09 package [34]. All the calculations were performed for $\left[\mathrm{Nb}_{6} \mathrm{O}_{19}\right]^{8-}$, and the other calculations except the optimization of electronic transition structure and emission energies were performed for $\left[\mathrm{Nb}_{10} \mathrm{O}_{28}\right]^{6-}$ and $\left[\mathrm{Ti}_{2} \mathrm{Nb}_{8} \mathrm{O}_{28}\right]^{8-}$. The ion $\left[\mathrm{H}_{2} \mathrm{Si}_{4} \mathrm{Nb}_{16} \mathrm{O}_{56}\right]^{14-}$ is so large that the present computational level can not deal with it at an acceptable accuracy.

\section{RESULTS AND DISCUSSION}

\subsection{Photoluminescence of These PONbs}

As shown in the Figure 1, the Lindqvist ion $\left[\mathrm{Nb}_{6} \mathrm{O}_{19}\right]^{8-}$ has a central $\mu_{6}-\mathrm{O}$ site, $12 \mu_{2}-\mathrm{O}$ bridges and 6 terminal $\eta$-O sites. The decaniobate $\left[\mathrm{Nb}_{10} \mathrm{O}_{28}\right]^{6-}$ has 10 niobium atoms in one molecular, while $\left[\mathrm{Ti}_{2} \mathrm{Nb}_{8} \mathrm{O}_{28}\right]^{8-}$ has eight niobium atoms and two Ti(IV) atoms replacing the two central $\mathrm{Nb}(\mathrm{V})$ atoms. The larger ion $\left[\mathrm{H}_{2} \mathrm{Si}_{4} \mathrm{Nb}_{16} \mathrm{O}_{56}\right]^{16-}$ has a lacunary, partial Keggin structure. The synthesis of $\mathrm{K}_{7}\left[\mathrm{HNb}_{6} \mathrm{O}_{19}\right], \mathrm{K}_{6}\left[\mathrm{Nb}_{10} \mathrm{O}_{28}\right], \mathrm{K}_{8}\left[\mathrm{Ti}_{2} \mathrm{Nb}_{8} \mathrm{O}_{28}\right]$ and $\mathrm{K}_{14} \mathrm{H}_{2}$ $\left[\mathrm{Si}_{4} \mathrm{Nb}_{16} \mathrm{O}_{56}\right]$ were according to the corresponding references, [7-11] and all the PONbs were characterized by solution-state ${ }^{17} \mathrm{O}-\mathrm{NMR}$ technique. As shown in Figure S1, the $\left[\mathrm{Nb}_{6} \mathrm{O}_{19}\right]^{8-}$ shows the signals at $393 \mathrm{ppm}$ and 623 ppm for $\mu_{2}-\mathrm{O}$ and $\eta$-O respectively, but the signal for central oxygen atom is not detected since the central

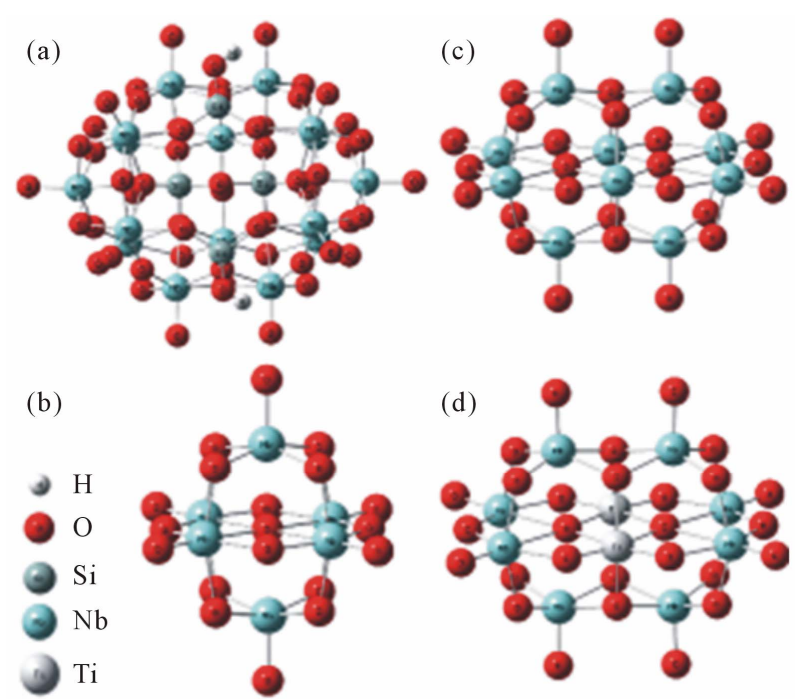

Figure 1. Structures of $\left[\mathrm{Nb}_{6} \mathrm{O}_{19}\right]^{8-}$ (b), $\left[\mathrm{Nb}_{10} \mathrm{O}_{28}\right]^{6-}$ (c), $\left[\mathrm{Ti}_{2} \mathrm{Nb}_{8} \mathrm{O}_{28}\right]^{8-}$ (d) and $\left[\mathrm{H}_{2} \mathrm{Si}_{4} \mathrm{Nb}_{16} \mathrm{O}_{56}\right]^{14-}$ (a) from their crystal structures $[7,8,14,15]$.

oxygen atom was not exchanged with ${ }^{17} \mathrm{O}$ water, which is consistent with the intertness of the central oxygen atom of $\left[\mathrm{Nb}_{10} \mathrm{O}_{28}\right]^{6-}$ found by Casey's group [17]. $\left[\mathrm{Nb}_{10} \mathrm{O}_{28}\right]^{6-}$ shows its characteristic chemical shifts from different sites (Figure S2), consistent with the result in the literature [18]. Major signals of ${ }^{17} \mathrm{O}-\mathrm{NMR}$ for $\left[\mathrm{Ti}_{2} \mathrm{Nb}_{8} \mathrm{O}_{28}\right]^{8-}$ was also detected (Figure S3), and the lack of the other signals may be induced by the low concentration and incomplete exchange with ${ }^{17} \mathrm{O}$-enriched water [19]. The large cluster $\left[\mathrm{H}_{2} \mathrm{Si}_{4} \mathrm{Nb}_{16} \mathrm{O}_{56}\right]^{14-}$ was also confirmed by ${ }^{17} \mathrm{O}$-NMR through comparing the chemical shifts at 50 ppm, 195 ppm, 394 ppm and 608 ppm (Figure S4) with the reported data [20].

It is the first time to observe the ultraviolet-visible luminescence of PONbs in aqueous solution at room temperature. Figure 2 shows the excitation and emission spectra of the PONbs inculding $\left[\mathrm{Nb}_{6} \mathrm{O}_{19}\right]^{8-},\left[\mathrm{Nb}_{10} \mathrm{O}_{28}\right]^{6-}$, $\left[\mathrm{Ti}_{2} \mathrm{Nb}_{8} \mathrm{O}_{28}\right]^{8-}$ and $\left[\mathrm{H}_{2} \mathrm{Si}_{4} \mathrm{Nb}_{16} \mathrm{O}_{56}\right]^{14-}$. The isopolyoxobionates $\left[\mathrm{Nb}_{6} \mathrm{O}_{19}\right]^{8-}$ and $\left[\mathrm{Nb}_{10} \mathrm{O}_{28}\right]^{6-}$ have close central emission wavelengths at around $400 \mathrm{~nm}$ with a small difference of $10 \mathrm{~nm}$ under their excitation wavelength of $294 \mathrm{~nm}$ and $310 \mathrm{~nm}$ respectively. $\left[\mathrm{Ti}_{2} \mathrm{Nb}_{8} \mathrm{O}_{28}\right]^{8-}$ exhibits the emission around $420 \mathrm{~nm}$ at the excitation wavelength of $306 \mathrm{~nm}$, while the larger cluster $\left[\mathrm{H}_{2} \mathrm{Si}_{4} \mathrm{Nb}_{16} \mathrm{O}_{56}\right]^{14-}$ emits the light band at $390 \mathrm{~nm}$, which suggests the role of introduced foreigner elements. The PONbs including $\left[\mathrm{Nb}_{6} \mathrm{O}_{19}\right]^{8-},\left[\mathrm{Nb}_{10} \mathrm{O}_{28}\right]^{6-}$ and $\left[\mathrm{H}_{2} \mathrm{Si}_{4} \mathrm{Nb}_{16} \mathrm{O}_{56}\right]^{14-}$ exhibit a similar blue light under the UV lamp as shown in Figure 2, while $\left[\mathrm{Ti}_{2} \mathrm{Nb}_{8} \mathrm{O}_{28}\right]^{8-}$ shows a green fluorescence. In order to explore the nature of the photoluminescence, we determined their lifetimes and quantum yields listed in Table 1. Their lifetimes are less than $10 \mathrm{~ns}$, indicating that their photoluminescence is originated from fluorescence, similar with luminescence of aluminum polyoxo- 


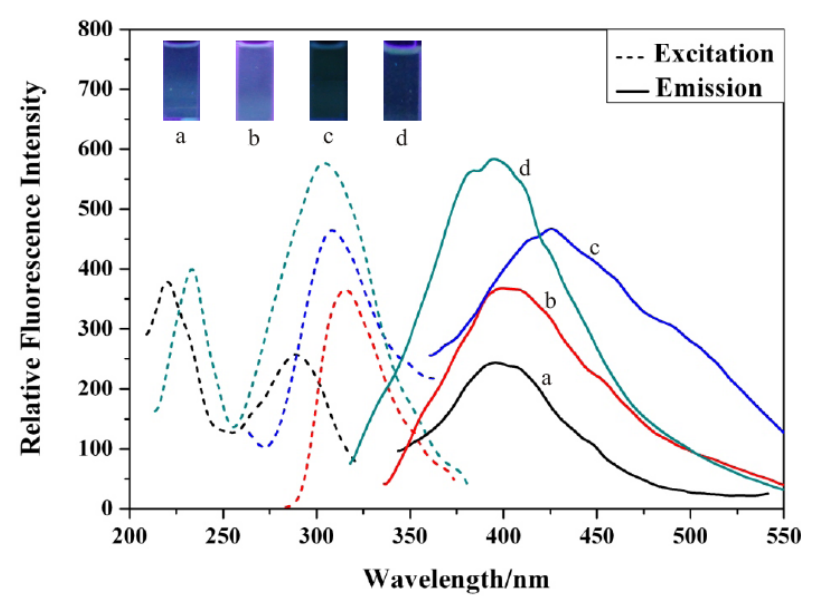

Figure 2. The photoluminescence spectra of $\left[\mathrm{Nb}_{6} \mathrm{O}_{19}\right]^{8-}$ (a), $\left[\mathrm{Nb}_{10} \mathrm{O}_{28}\right]^{6-}$ (b), $\left[\mathrm{Ti}_{2} \mathrm{Nb}_{8} \mathrm{O}_{28}\right]^{8-}$ (c) and $\left[\mathrm{H}_{2} \mathrm{Si}_{4} \mathrm{Nb}_{16} \mathrm{O}_{56}\right]^{14-}$ (d) and their visible fluorescence photographs.

Table 1. The fluorescence quantum yields and lifetimes of $\left[\mathrm{Nb}_{6} \mathrm{O}_{19}\right]^{8-},\left[\mathrm{Nb}_{10} \mathrm{O}_{28}\right]^{6-},\left[\mathrm{Ti}_{2} \mathrm{Nb}_{8} \mathrm{O}_{28}\right]^{8-}$ and $\left[\mathrm{H}_{2} \mathrm{Si}_{4} \mathrm{Nb}_{16} \mathrm{O}_{56}\right]^{14-}$.

\begin{tabular}{ccccc}
\hline Sample & {$\left[\mathrm{Nb}_{6} \mathrm{O}_{19}\right]^{8-}$} & {$\left[{\left.\mathrm{Nb} 10 \mathrm{O}_{28}\right]^{6-}}^{6}\right.$} & {$\left[\mathrm{Ti}_{2} \mathrm{Nb}_{8} \mathrm{O}_{28}\right]^{8-}$} & {$\left[\mathrm{H}_{2} \mathrm{Si}_{4} \mathrm{Nb}_{16} \mathrm{O}_{56}\right]^{14-}$} \\
\hline$\Phi^{\mathrm{a}}(\%)$ & 0.067 & 0.51 & 0.13 & 1.1 \\
$\tau^{\mathrm{b}}(\mathrm{ns})$ & 4.2 & 7.2 & 7.2 & 8.7 \\
\hline
\end{tabular}

${ }^{\mathrm{a}}$ The fluorescence quantum yields relative to quinine sulfate $(0.577) .{ }^{\mathrm{b}} \mathrm{The}$ average lifetimes.

cations [24]. The quantum yields are increased with their sizes except $\left[\mathrm{Ti}_{2} \mathrm{Nb}_{8} \mathrm{O}_{28}\right]^{8-}$, and the incorporation of $\mathrm{Ti}$ into $\left[\mathrm{Nb}_{10} \mathrm{O}_{28}\right]^{6-}$ lowers the quantum yield.

In order to explore the nature of the fluorescence of these PONbs, we carried out DFT calculations on them. The geometries were optimized from their X-ray crystal structure with consideration of solvent effects. The electronic transition components were calculated at TD-DFT level of theory [30-32]. The calculations show that the computational absorption maximum wavelengths for $\left[\mathrm{Nb}_{6} \mathrm{O}_{19}\right]^{8-},\left[\mathrm{Nb}_{10} \mathrm{O}_{28}\right]^{6-}$ and $\left[\mathrm{Ti}_{2} \mathrm{Nb}_{8} \mathrm{O}_{28}\right]^{8-}$ are very close to their experimental data (Table S1). The largest contribution to actual transition for $\left[\mathrm{Nb}_{6} \mathrm{O}_{19}\right]^{8-}$ is the transition from $\mathrm{HOMO}-1$ to $\mathrm{LUMO}+4$, and five additional transitions also contribute to excitation wavelength $294 \mathrm{~nm}$ (Figure S5). The electronic transitions contributing largest to actual transitions for $\left[\mathrm{Nb}_{10} \mathrm{O}_{28}\right]^{6-}$ and $\left[\mathrm{Ti}_{2} \mathrm{Nb}_{8} \mathrm{O}_{28}\right]^{8-}$ are from HUMO-3 to LOMO and from HOMO to LUMO+3 respectively (Figures S6 and S7). All the transitions with largest contribution involve the electron transfer from $\mu_{2}-\mathrm{O}$ to $\eta$-O, indicating their distinctive characteristics. We take $\left[\mathrm{Nb}_{6} \mathrm{O}_{19}\right]^{8-}$ as an example to demonstrate the whole absorption and emission process in the view of molecular orbital as shown in Figure 3. Six one-electron transitions including the transition from HOMO-1 to LUMO+3 with largest contribution result in the actual excitation (absorption) wavelength $294 \mathrm{~nm}$.

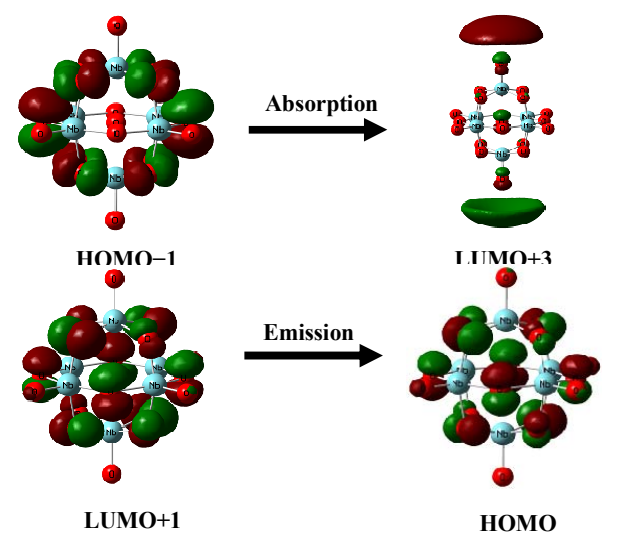

Figure 3. The electron-transitions with the largest contribution to actual absorption wavelength and emission wavelength of $\left[\mathrm{Nb}_{6} \mathrm{O}_{19}\right]^{8-}$ respectively.

The structure of the excited ion quickly changes after the transition occurs. Following internal conversion, the electron reaches the lowest energy vibrational state of $\mathrm{S}_{1}$. The structure of $\left[\mathrm{Nb}_{6} \mathrm{O}_{19}\right]^{8-}$ at $\mathrm{S}_{1}$ state was built with TD-optimization. The TD-calculations show the fluorescence emission is from the transition between LUMO+1 and HOMO. These results show the key role of $\mu_{2}-\mathrm{O}$ and $\eta$-O atoms in the photoluminescence properties of these PONbs.

\subsection{Electrocatalytic Activities of These PONbs for Water Oxidation}

It was reported that manganese complexes, ruthenium complexes, cobalt complexes and iridium oxide colloid can be used as efficient catalysts for electrochemical water oxidation [35]. Except for cobalt complexes, it was found that cobalt polyoxometalates can also be used to splitting water, and the dominant water oxidation catalyst is actually heterogeneous cobalt oxides [36]. Ruthenium polyoxometalate cluster attached on carbon nanotubes was also shown as a very efficient and stable water oxidation catalyst.

These reports demonstrated that the efficient water oxidation catalysts are mainly composed of manganese, ruthenium, cobalt and iridium. However, herein we resented that the PONbs have high electrocatalytic activities for water oxidation under basic condition. Figure 4 shows the electrocatalytic activities of these PONbs for water oxidation. An oxidation process is evident at 1.35 $\mathrm{V}$ and $1.48 \mathrm{~V}$ for $\left[\mathrm{Nb}_{10} \mathrm{O}_{28}\right]^{6-}$ and $\left[\mathrm{H}_{2} \mathrm{Si}_{4} \mathrm{Nb}_{16} \mathrm{O}_{56}\right]^{14-}$ respectively, and generates a significant rise in the current consistent with a catalytic process. The maximum peak current of $\left[\mathrm{Nb}_{10} \mathrm{O}_{28}\right]^{6-}$ is five times larger than that for the blank solution, while that for $\left[\mathrm{Si}_{4} \mathrm{Nb}_{16} \mathrm{O}_{56}\right]^{16-}$ is nearly tenfold the blank solution. The rise in current around 1.4 $\mathrm{V}$ is attributed to oxidation of water catalyzed by 


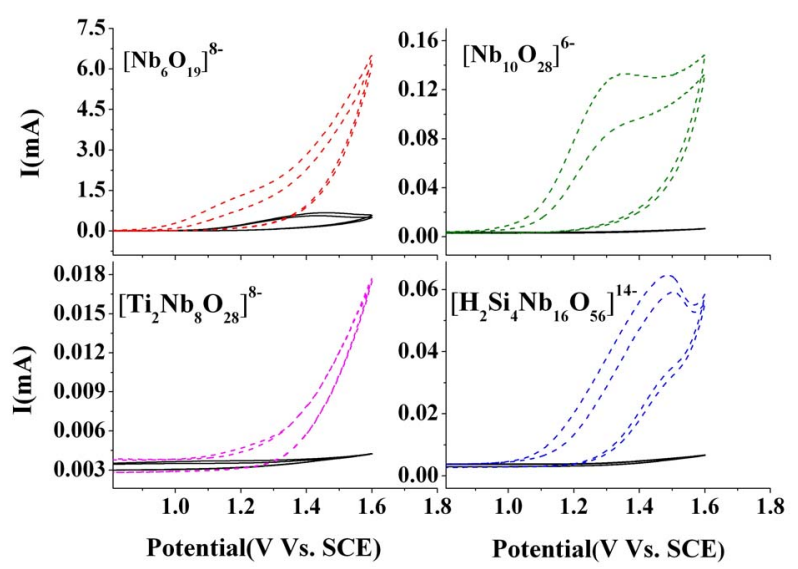

Figure 4. Cyclic voltammograms for $\left[\mathrm{Nb}_{6} \mathrm{O}_{19}\right]^{8-}$ at $\mathrm{pH} 13.7$, $\left[\mathrm{Nb}_{10} \mathrm{O}_{28}\right]^{6-}$ at $\mathrm{pH}$ 9.1, $\left[\mathrm{Ti}_{2} \mathrm{Nb}_{8} \mathrm{O}_{28}\right]^{8-}$ at $\mathrm{pH} 8.6,\left[\mathrm{H}_{2} \mathrm{Si}_{4} \mathrm{Nb}_{16} \mathrm{O}_{56}\right]^{14-}$

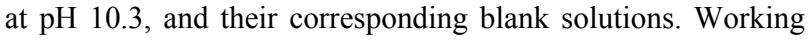
electrode, platinum disk electrode; scan rate, $100 \mathrm{mV} / \mathrm{s}$.

$\left[\mathrm{Nb}_{10} \mathrm{O}_{28}\right]^{6-}$ and $\left[\mathrm{H}_{2} \mathrm{Si}_{4} \mathrm{Nb}_{16} \mathrm{O}_{56}\right]^{14-}$, and the potentials at maximum current of water oxidation are close to those reported in the similar catalytic processes. The currents for $\left[\mathrm{Nb}_{6} \mathrm{O}_{19}\right]^{8-}$ and $\left[\mathrm{Ti}_{2} \mathrm{Nb}_{8} \mathrm{O}_{28}\right]^{8-}$ solutions are alsoby several times relative to those for the blank although their CVs have no remarkable peak currents. This electrocatalytic behaviors of $\left[\mathrm{Nb}_{6} \mathrm{O}_{19}\right]^{8-}$ and $\left[\mathrm{Ti}_{2} \mathrm{Nb}_{8} \mathrm{O}_{28}\right]^{8-}$ is similar to POM supported on multi-walled carbon nanotubes [37-39].

The possibility of a catalytically active niobium oxide film generated by the decomposition is excluded by homogeneity test of electrode surface from $\left[\mathrm{Nb}_{6} \mathrm{O}_{19}\right]^{8-}$ solution. As shown in Figure 5, the cyclic voltammetric response of working electrode in a blank electrolyte following two anodic cycles from $0-1.8 \mathrm{~V}$ vs SCE in 1 $\mathrm{mM}$ of $\left[\mathrm{Nb}_{6} \mathrm{O}_{19}\right]^{8-}$. The electrode was taken out of the solution, washed by distilled water and continued to the test. The current after removing $\left[\mathrm{Nb}_{6} \mathrm{O}_{19}\right]^{8-}$ is much lower than that for $\left[\mathrm{Nb}_{6} \mathrm{O}_{19}\right]^{8-}$ and close to that for the blank solution, which demonstrated that the true water oxidation catalyst is the ion $\left[\mathrm{Nb}_{6} \mathrm{O}_{19}\right]^{8-}$ in solution rather than the niobium oxide formed on the electrode surface. The dependence of the catalytic current on concentration of $\left[\mathrm{Nb}_{6} \mathrm{O}_{19}\right]^{8-}$ shown in Figure 6 also supported the key role of these PONbs in the catalysis. From the figure one can see clearly the current of $\left[\mathrm{Nb}_{6} \mathrm{O}_{19}\right]^{8-}$ was increased as the concentration rises, demonstrating the dependence of the catalytic current on concentration of $\left[\mathrm{Nb}_{6} \mathrm{O}_{19}\right]^{8-}$ in aqueous solution. We also tested the influence of $\mathrm{pH}$ values on the electrocatalytic behavior of $\left[\mathrm{Nb}_{6} \mathrm{O}_{19}\right]^{8-}$ for water oxidation. As shown in Figure 7, the catalytic current is increased as $\mathrm{pH}$ values, but electrocatalytic behaviors of these PONbs for water oxidation were not remarkably affected by the variety of $\mathrm{pH}$ values, which indicated that the number of protons and charges of the PONbs would affect their electrocatalytic activities.

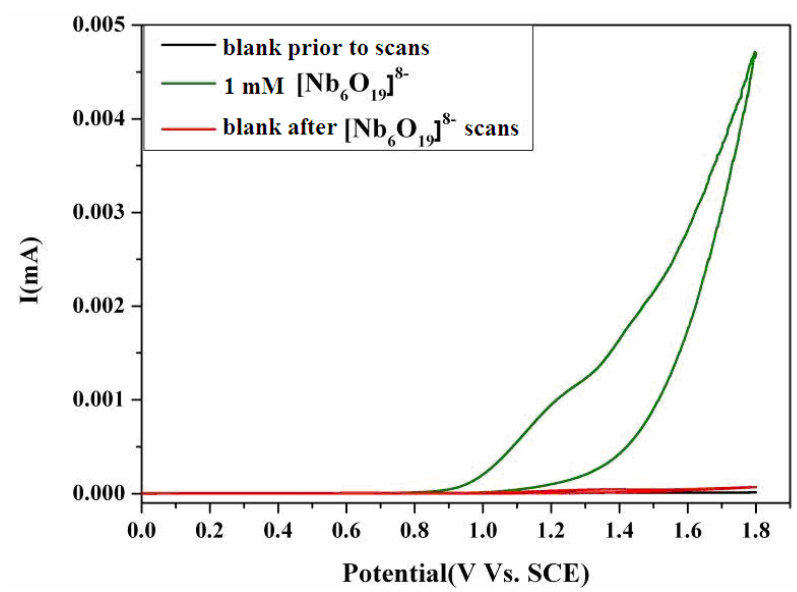

Figure 5. Homogeneity test of electrode surface from dilute $\left[\mathrm{Nb}_{6} \mathrm{O}_{19}\right]^{8-}$ solutions. The cyclic voltammetric response of glassy carbon working electrode in distilled water (black) and $\left[\mathrm{Nb}_{6} \mathrm{O}_{19}\right]^{8-}$ (green) at the same $\mathrm{pH}$ of 13 were detected (scan rate $=10 \mathrm{mV} / \mathrm{s}$ ), and after gently washing the electrode with distilled $\mathrm{H}_{2} \mathrm{O}$ then scanning in blank electrolyte (red).

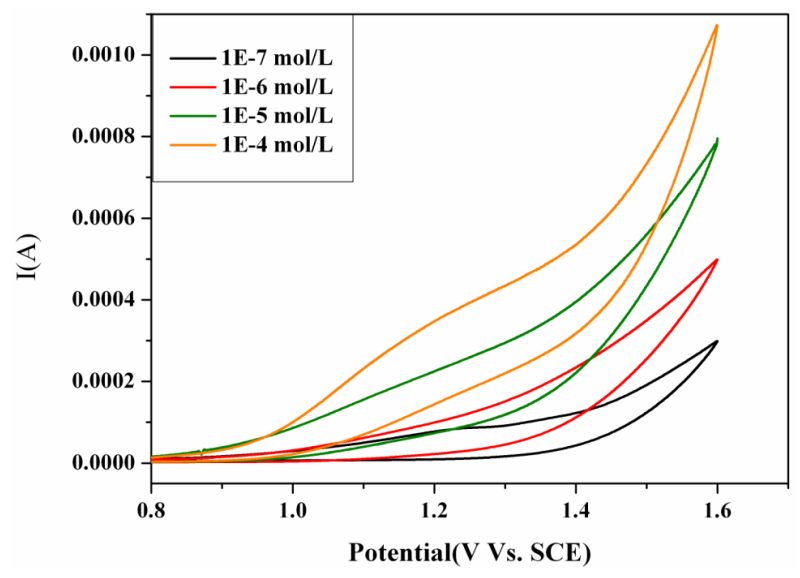

Figure 6. Cyclic voltammograms of $\left[\mathrm{Nb}_{6} \mathrm{O}_{19}\right]^{8-}$ with different concentrations recorded in aqueous solution $(\mathrm{pH}=12$, scan rate $=10 \mathrm{mV} / \mathrm{s}$ ).

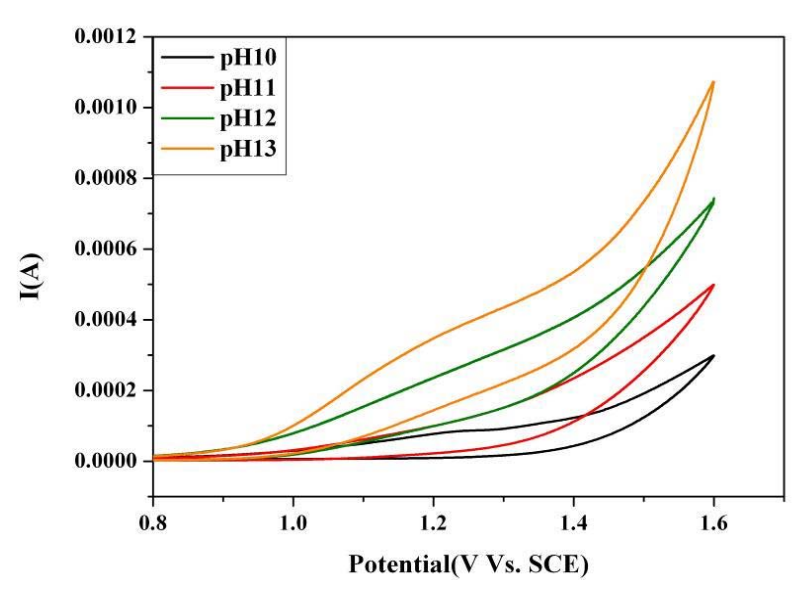

Figure 7. Cyclic voltammograms of $\left[\mathrm{Nb}_{6} \mathrm{O}_{19}\right]^{8-}$ under different $\mathrm{pH}$ conditions recorded in aqueous solution (scan rate $=10$ $\mathrm{mV} / \mathrm{s})$. 
However, the redox chemistry of these PONbs underlying the electrocatalytic processes is needed to further explore.

\section{CONCLUSION}

In summary, we provided the examples of PONbs for their novel photoluminescence and potential redox chemistry. The photoluminescence of $\left[\mathrm{Nb}_{6} \mathrm{O}_{19}\right]^{8-},\left[\mathrm{Nb}_{10} \mathrm{O}_{28}\right]^{6-}$, $\left[\mathrm{Ti}_{2} \mathrm{Nb}_{8} \mathrm{O}_{28}\right]^{8-}$ and $\left[\mathrm{H}_{2} \mathrm{Si}_{4} \mathrm{Nb}_{16} \mathrm{O}_{56}\right]^{14-}$ was observed, the tunable ability of their fluorescence by foreign atoms was demonstrated, and the origin of the fluorescence was revealed in the view of molecular orbital theory. The luminescence of these PONbs gives a good example for optical response of the other polyoxometalates. The high performance of these PONbs on water oxidation was also demonstrated, which implies their huge potential application for splitting water, and opens the door to redox chemistry of PONbs.

\section{SUPPLEMENTARY MATERIAL}

Characterization of PONbs ${ }^{17} \mathrm{O}$ NMR, computational results (electronic transition components and molecular orbitals).

\section{ACKNOWLEDGEMENTS}

We are thankful for the supports by Chinese National Natural Science Foundation (No. 21005073) and Foundation of Zhejiang Province (No. LY13B050001, LQ13B050002 and Y201225601) and Xin Miao Talents Planning of Zhejiang Province (2012R404038).

\section{REFERENCES}

[1] Rhule, J.T., Hill, C.L. and Judd, D.A. (1998) Polyoxometalates in medicine. Chemial Review, 98, 327-357. doi:10.1021/cr960396q

[2] Nyman, M., Bonhomme, F., Alam, T.M., Rodriguez, M. A., Cherry, B.R., Krumhansl, J.L., Nenoff, T.M. and Sattler, A.M. (2002) A general synthetic procedure for heteropolyniobates. Science, 297, 996-998.

[3] Kudo, A. and Miseki, Y. (2009) Heterogeneous photocatalyst materials for water splitting. Chemical Society Review, 38, 253-278. doi:10.1039/b800489g

[4] Rustad, J.R. and Casey, W.H. (2012) Destruction of the Kondo effect in the cubic heavy-fermion compound $\mathrm{Ce}_{3} \mathrm{Pd}_{20} \mathrm{Si}_{6}$. Nature Material, 11, 189-194. doi:10.1038/nmat3214

[5] Nyman, M. (2011) Polyoxoniobate chemistry in the 21st century. Dalton Transactions, 40, 8049-8058. doi:10.1039/c1dt10435g

[6] Casey, W.H., Rustad, J.R. and Spiccia, L. (2009) Minerals as molecules-use of aqueous oxide and hydroxide clusters to understand geochemical reactions. Chemical Europe Journal, 15, 4496-4515.

\section{doi:10.1002/chem.200802636}

[7] Lindqvist, I. (1952) The structure of the hexaniobate ion in $7 \mathrm{Na}_{2} \mathrm{O} \cdot 6 \mathrm{Nb}_{2} \mathrm{O}_{5} \cdot 32 \mathrm{H}_{2} \mathrm{O}$. Ark Kemi, 5, 247-250.

[8] Graeber, E.J. and Morosin, B. (1977) The molecular configuration of the decaniobate ion $\left(\mathrm{Nb}_{10} \mathrm{O}_{28}^{6-}\right)$. Acta Crystallographica, Section B, 33, 2137-2143. doi:10.1107/S0567740877007900

[9] Maekawa, M., Ozawa, Y. and Yagasaki, A. (2005) Icosaniobate: A new member of the isoniobate family Inorganic Chemistry, 45, 9608-9609.

[10] Ranko, P. and Nyman, M. (2006) Evolution of polyoxoniobate cluster anions. Angewandte Chemie International Edition, 45, 6670-6672. doi:10.1002/anie.200602200

[11] Nyman, M., Bonhomme, F., Alam, T.M., Parise, J.B. and Vaughan, G.M.B. (2004) $\left[\mathrm{SiNb}_{12} \mathrm{O}_{40}\right]^{16-}$ and $\left[\mathrm{GeNb}_{12} \mathrm{O}_{40}\right]^{16-}$ : Highly charged keggin ions with sticky surfaces. Angewandte Chemie International Edition, 43, 2787-2792. doi:10.1002/anie.200353410

[12] Nyman, M., Celestian, A.J., Parise, J.B., Holland, G.P. and Alam, T.M. (2006) Solid-state structural characterization of a rigid framework of lacunary heteropolyniobates. Inorganic Chemistry, 45, 1043-1052. doi:10.1021/ic051155g

[13] Ohlin, C.A., Villa, E.M., Fettinger, J.C. and Casey, W.H. (2008) The $\left[\mathrm{Ti}_{12} \mathrm{Nb}_{6} \mathrm{O}_{44}\right]^{10-}$ ion-A new type of polyoxometalate structure. Angewandte Chemie International Edition, 47, 5634-5636. doi:10.1002/anie.200801883

[14] Ohlin, C.A., Villa, E.M., Fettinger, J.C. and Casey, W.H. (2009) A new titanoniobate ion-completing the series $\left[\mathrm{Nb}_{10} \mathrm{O}_{28}\right]^{6-}, \quad\left[\mathrm{TiNb}_{9} \mathrm{O}_{28}\right]^{7-}$ and $\left[\mathrm{Ti}_{2} \mathrm{Nb}_{8} \mathrm{O}_{28}\right]^{8-}$. Dalton Transactions, 15, 2677-2678. doi:10.1039/b900465c

[15] Johnson, R.L., Villa, E.M., Ohlin, C.A., Rustad, J.R. and Casey, W.H. (2011) ${ }^{17} \mathrm{O}$ NMR and computational study of a tetrasiliconiobate ion, $\left[\mathrm{H}^{2+\mathrm{x}} \mathrm{Si}_{4} \mathrm{Nb}_{16} \mathrm{O}_{56}\right]^{(14-\mathrm{x})-}$. Chemical Europe Journal, 17, 9359-9367. doi:10.1002/chem.201100004

[16] Huang, P., Qin, C., Wang, X.L., Sun, C.Y., Xing, Y., Wang, H.N., Shao, K.Z. and Su, Z.M. (2012) A new organic-inorganic hybrid based on the crescent-shaped polyoxoanion $\left[\mathrm{H}_{6} \mathrm{SiNb}_{18} \mathrm{O}_{54}\right]^{8-}$ and copper-organic cations. Dalton Transactions, 41, 6075-6077. doi:10.1039/c2dt30265a

[17] Black, J.R., Nyman, M. and Casey, W.H. (2006) Rates of oxygen exchange between the $\left[\mathrm{H}_{\mathrm{x}} \mathrm{Nb}_{6} \mathrm{O}_{19}\right]^{8-\mathrm{x}}(\mathrm{aq})$ lindqvist ion and aqueous solutions. Journal American Chemical Society, 128, 14712-14720.

[18] Villa, E.M., Ohlin, C.A., Balogh, E., Anderson, T.M., Nyman, M.D. and Casey, W.H. (2008) Reaction dynamics of the decaniobate ion $\left[\mathrm{H}_{\mathrm{x}} \mathrm{Nb}_{10} \mathrm{O}_{28}\right]^{(6-\mathrm{x})^{-}}$in Water. $A n-$ gewandte Chemie International Edition, 47, 4844-4846. doi:10.1002/anie.200801125

[19] Villa, E.M., Ohlin, A., Rustad, J.R. and Casey, W.H. (2009) Isotope-exchange dynamics in isostructural decametalates with profound differences in reactivity. Journal of American Chemical Society, 131, 1648816492. doi: $10.1021 /$ ja905166c

[20] Johnson, R.L., Villa, E.M., Ohlin, C.A., Rustad, J.R. and Casey, W.H. (2011) ${ }^{17}$ O NMR and computational study 
of a tetrasiliconiobate ion, $\left[\mathrm{H}^{2+x} \mathrm{Si}^{4} \mathrm{Nb}^{16} \mathrm{O}^{56}\right]^{(14-\mathrm{x})-}$. Chemical Europe Journal, 17, 9359-9367. doi:10.1002/chem.201100004

[21] Antonio, M.R., Nyman, M. and Anderson, T.M. (2009) Direct observation of contact ion-pair formation in aqueous solution, Angewandte Chemie International Edition, 48, 6136-6140. doi:10.1002/anie.200805323

[22] Ohlin, C.A., Villa, E.M., Fettinger, J.C. and Casey, W.H. (2008) Distinctly different reactivities of two similar polyoxoniobates with hydrogen peroxide. Angewandte Chemie International Edition, 47, 8251-8254. doi:10.1002/anie.200803688

[23] Zhou, X.F., Li, Z.C., Wang, Y.Q., Sheng, X. and Zhang, Z.J. (2008) Photoluminescence of amorphous niobium oxide films synthesized by solid-state reaction. Thin Solid Films, 516, 4213-4216. doi:10.1016/j.tsf.2007.12.112

[24] Qian, Z.S., Chen, C.C., Chen, J.R., Kong, L.C., Wang, C., Zhou, J. and Feng, H. (2011) Unusual visible luminescence of aluminium polyoxocations in aqueous Solution. Chemical Communication, 47, 12652-12654. doi:10.1039/c1cc15823f

[25] Musa, K.A.K. and Eriksson, L.A. (2009) Photodegradation mechanism of nonsteroidal anti-inflammatory drugs containing thiophene moieties: Suprofen and tiaprofenic acid. Journal of Physical Chemistry B, 113, 11306-11313. doi:10.1021/jp904171p

[26] Cardenas-Jiron, G.I., Barboza, C.A., Lopez, R. and Menendez, M.I. (2011) Theoretical study on the electronic excitations of a porphyrin-polypyridyl ruthenium (II) photosensitizer. Journal of Physical Chemistry A, 115, 11988-11997. doi:10.1021/jp202377d

[27] Tomasi, J., Mennucci, B., Cammi, R. (2005) Quantum mechanical continuum solvation models. Chemical Review, 105, 2999-3094. doi:10.1021/cr9904009

[28] Runge, E. and Gross, E.K.U. (1984) Density-functional theory for time-dependent systems. Physical Review Letters, 52, 997-1000. doi:10.1103/PhysRevLett.52.997

[29] Scalmani, G., Frisch, M.J., Mennucci, B., Tomasi, J., Cammi, R. and Barone, V. (2006) Geometries and properties of excited states in the gas phase and in solution: Theory and application of a time-dependent density functional theory polarizable continuum model. Journal of Chemical Physics, 124, 94-107.

[30] Dreuw, A., Plotner, J., Lorenz, L., Wachtveitl, J., Djanhan, J.E., Bruning, J., Metz, T., Bolte, M. and Schmidt, M.U. (2005) Molecular mechanism of the solid-state fluorescence behavior of the organic pigment yellow 101 and its derivatives. Angewandte Chemie International Edition, 44, 7787-7786. doi:10.1002/anie.200501781

[31] Fortage, J., Peltier, C., Perruchot, C., Takemoto, Y., Teki, Y., Bedioui, F., Marvaud, V., Dupeyre, G., Pospisil, L., Adamo, C., Hromadova, M., Ciofini, I. and Laine, P.P. (2012) Single-step versus stepwise two-electron reduction of polyarylpyridiniums: Insights from the steric switching of redox potential compression. Journal of Chemical Physics, 134, 2691-2705.

[32] Bereau, V., Duhayon, C., Sournia-Saquet, A. and Sutter,
J.-P. (2012) Tuning of the emission efficiency and HOMO-LUMO band gap for ester-functionalized $\left\{\mathrm{Al}(\text { salophen })\left(\mathrm{H}_{2} \mathrm{O}\right)_{2}\right\}^{+}$blue luminophors. Inorganic Chemistry, 51, 1309-1318. doi:10.1021/ic201208c

[33] Reed, A.E., Curtiss, L.A. and Weinhold, F. (1988) Intermolecular interactions from a natural bond orbital, donor-acceptor viewpoint. Chemical Review, 88, 899-926. doi: $10.1021 / \mathrm{cr} 00088 \mathrm{a} 005$

[34] Frisch, M.J., Trucks, G.W., Schlegel, H.B., Scuseria, G.E., Robb, M.A., Cheeseman, J.R., Scalmani, G., Barone, V., Mennucci, B., Petersson, G.A., Nakatsuji, H., Caricato, M., Li, X., Hratchian, H.P., Izmaylov, A.F., Bloino, J., Zheng, G., Sonnenberg, J.L., Hada, M., Ehara, M., Toyota, K., Fukuda, R., Hasegawa, J., Ishida, M., Nakajima, T., Honda, Y., Kitao, O., Nakai, H., Vreven, T., Montgomery, J.A., Peralta, J.E., Ogliaro, F., Bearpark, M., Heyd, J.J., Brothers, E., Kudin, K.N., Staroverov, V. N., Kobayashi, R., Normand, J., Raghavachari, K., Rendell, A., Burant, J.C., Iyengar, S.S., Tomasi, J., Cossi, M., Rega, N., Millam, J.M., Klene, M., Knox, J.E., Cross, J.B., Bakken, V., Adamo, C., Jaramillo, J., Gomperts, R., Stratmann, Yazyev, O., Austin, A.J., Cammi, R., Pomelli, C., Ochterski, J.W., Martin, R.L., Morokuma, K., Zakrzewski, V.G., Voth, G. A., Salvador, P., Dannenberg, J.J., Dapprich, S., Daniels, A.D., Farkas, O., Foresman, J. B., Ortiz, J.V., Cioslowski, J. and Fox, D.J. (2009) Gaussian 09, Revision A.02, Gaussian, Inc., Wallingford CT.

[35] Stracke, J.J. and Finke, R.G. (2011) Electrocatalytic Water Oxidation Beginning with the Cobalt Polyoxometalate $\left[\mathrm{Co}_{4}\left(\mathrm{H}_{2} \mathrm{O}\right)_{2}\left(\mathrm{PW}_{9} \mathrm{O}_{34}\right)_{2}\right]^{10-}$ : Identification of heterogeneous $\mathrm{CoO}_{x}$ as the dominant catalyst. Journal of the American Chemical Society, 133, 14872-14875. doi:10.1021/ja205569j

[36] Toma, F.M., Sartorel, A., Lurlo, M., Carraro, M., Parisse, P., Maccato, C., Rapino, S., Gonzalez, B.R., Amenitsch, H., DaRos, G.T., Casalis, L., Goldoni, A., Marcaccio, M., Scorrano, G., Scoles, F., Paolucci, M. and Prato, B.M. (2010) Efficient water oxidation at carbon nanotubepolyoxometalate electrocatalytic interfaces. Nature Chemistry, 2, 826-831.

[37] Concepcion, J.J., Jurss, J.W., Hoertz, P.G. and Meyer, T.J. (2009) Catalytic and surface-electrocatalytic water oxidation by redox mediator-catalyst assemblies. Angewandte Chemie International Edition, 48, 9473-9476. doi:10.1002/anie.200901279

[38] Stracke, J.J. and Finke, R.G., (2011) Electrocatalytic Water Oxidation Beginning with the Cobalt Polyoxometalate $\left[\mathrm{Co}_{4}\left(\mathrm{H}_{2} \mathrm{O}\right)_{2}\left(\mathrm{PW}_{9} \mathrm{O}_{34}\right)_{2}\right]^{10-}$ : Identification of heterogeneous $\mathrm{CoO}_{x}$ as the dominant catalyst. Journal of the American Chemical Society, 133, 14872-14875. doi:10.1021/ja205569j

[39] Wasylenko, D.J., Palmer, R.D., Schott, E. and Berlinguette, C.P. (2012) Interrogation of electrocatalytic water oxidation mediated by a cobalt complex. Chemical Communications, 48, 2107-2109. doi:10.1039/c2cc16674g 


\section{SUPPORTING INFORMATION}

1. The ${ }^{17} \mathrm{O}$ NMR spectrum of $\left[\mathrm{Nb}_{6} \mathrm{O}_{19}\right]^{8-}$ in aqueous solution.

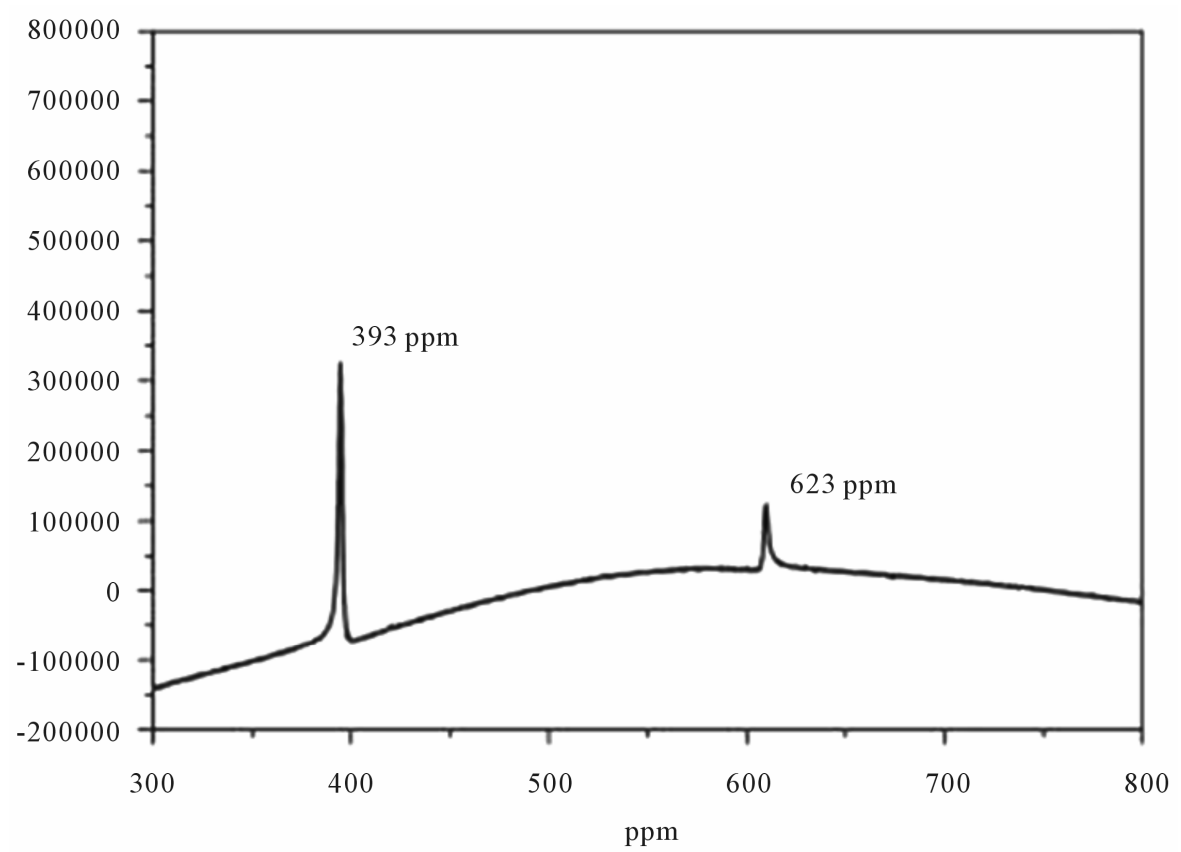

Figure S1. The ${ }^{17} \mathrm{O}$ NMR spectrum of $\left[\mathrm{Nb}_{6} \mathrm{O}_{19}\right]^{8-}$ in aqueous solution $(\mathrm{pH}=13, \mathrm{~T}=306 \mathrm{~K})$. The signal at $393 \mathrm{ppm}$ corresponds to $\mu_{2}-\mathrm{O}$, and the signal at $623 \mathrm{ppm}$ corresponds to $\eta$-O. The signal from central oxygen atom is too weak to detect because its inert hinder the exchange with ${ }^{17} \mathrm{O}$-enriched water.

\section{The ${ }^{17} \mathrm{O}$ NMR spectrum of $\left[\mathrm{Nb}_{10} \mathrm{O}_{28}\right]^{6-}$ in aqueous solution.}

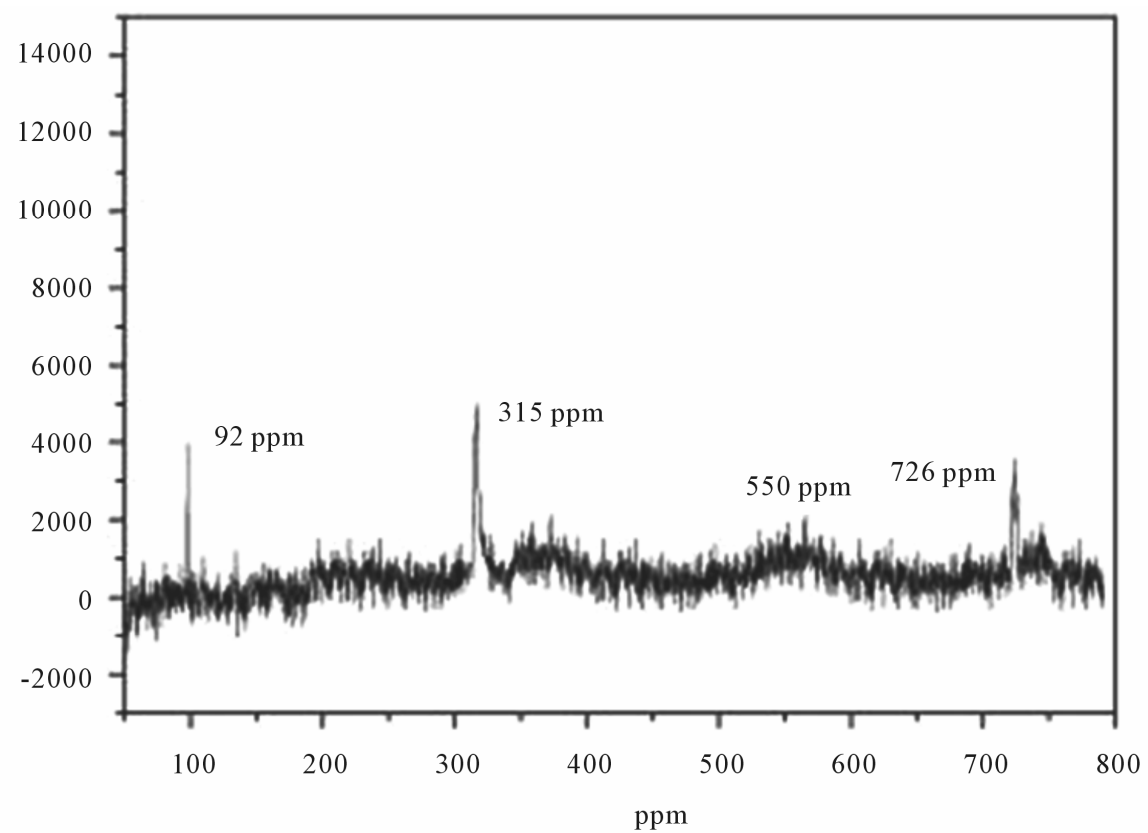

Figure S2. The ${ }^{17} \mathrm{O}$ NMR spectra of $\left[\mathrm{Nb}_{10} \mathrm{O}_{28}\right]^{6-}$ in aqueous solution $(\mathrm{pH}=10, \mathrm{~T}=306 \mathrm{~K})$. The characteristic signals at $92 \mathrm{ppm}, 315 \mathrm{ppm}, 550 \mathrm{ppm}$ and $726 \mathrm{pmm}$ are in accordance with the literature. 


\section{The ${ }^{17} \mathrm{O}$ NMR spectrum of $\left[\mathrm{Ti}_{2} \mathrm{Nb}_{8} \mathrm{O}_{28}\right]^{8-}$ in aqueous solution.}

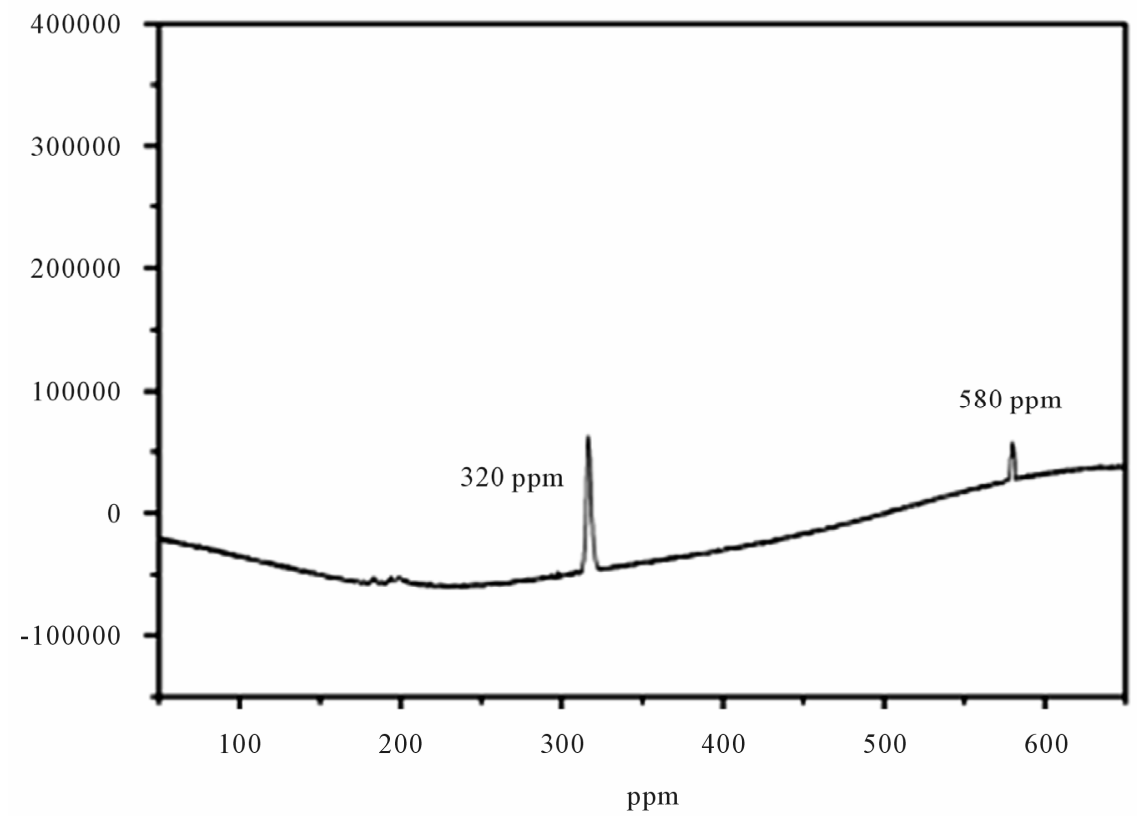

Figure S3. The ${ }^{17} \mathrm{O}$ NMR spectra of $\left[\mathrm{Ti}_{2} \mathrm{Nb}_{8} \mathrm{O}_{28}\right]^{8-}$ in aqueous solution $(\mathrm{pH}=8.3, \mathrm{~T}=306$ $\mathrm{K})$. The characteristic signals at $320 \mathrm{ppm}$ and $580 \mathrm{ppm}$ are shown and consistent with the literature. The lack of the other signals may be induced by the low concentration and incomplete exchange with ${ }^{17} \mathrm{O}$-enriched water.

\section{The ${ }^{17} \mathrm{O}$ NMR spectrum of $\left[\mathrm{H}_{2} \mathrm{Si}_{4} \mathrm{Nb}_{16} \mathrm{O}_{56}\right]^{14-}$ in aqueous solution.}

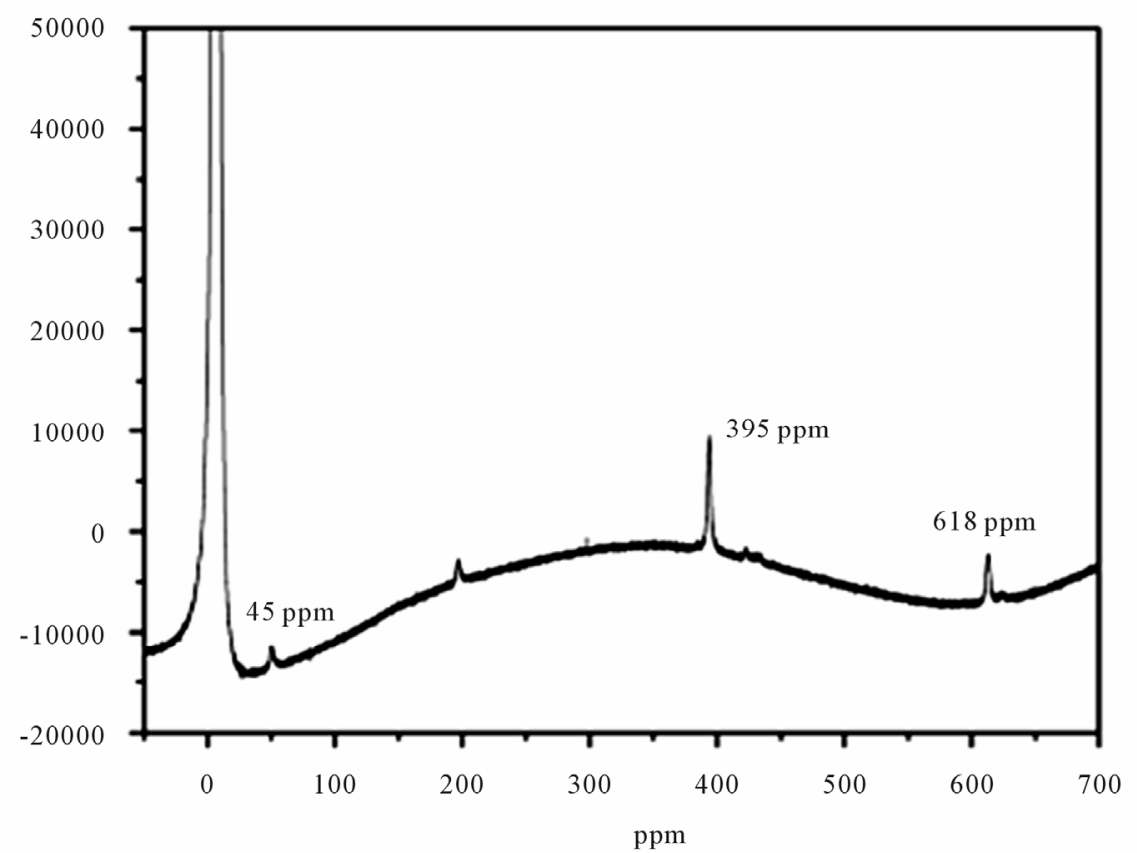

Figure S4. The ${ }^{17} \mathrm{O}$ NMR spectrum of $\left[\mathrm{H}_{2} \mathrm{Si}_{4} \mathrm{Nb}_{16} \mathrm{O}_{56}\right]^{14-}$ in aqueous solution $(\mathrm{pH}=10.2, \mathrm{~T}$ $=306 \mathrm{~K}$ ). The characteristic signals at $45 \mathrm{ppm}, 440 \mathrm{ppm}$ and $618 \mathrm{ppm}$ are shown and consistent with the literature. The lack of the other signals may be induced by the low concentration and incomplete exchange with ${ }^{17} \mathrm{O}$-enriched water. 
5. The experimental and calculated absorption maximum wavelengths, oscillator strength ( $f_{\text {calcd }}$ ), transitions and CI expansion coefficients (contributions) of $\left[\mathrm{Nb}_{6} \mathrm{O}_{19}\right]^{8-},\left[\mathrm{Nb}_{10} \mathrm{O}_{28}\right]^{6-}$ and $\left[\mathrm{Ti}_{2} \mathrm{Nb}_{8} \mathrm{O}_{28}\right]^{8-}$.

Table S1. The experimental and calculated absorption maximum wavelengths, oscillator strength ( $\mathrm{f}_{\text {calcd }}$ ), transitions and CI expansion coefficients (contributions) of $\left[\mathrm{Nb}_{6} \mathrm{O}_{19}\right]^{8-},\left[\mathrm{Nb}_{10} \mathrm{O}_{28}\right]^{6-}$ and $\left[\mathrm{Ti}_{2} \mathrm{Nb}_{8} \mathrm{O}_{28}\right]^{8-}$.

\begin{tabular}{|c|c|c|c|c|c|}
\hline & $\lambda_{\text {ex-expl }}(\mathrm{nm})$ & $\lambda_{\text {ex-cal }}(\mathrm{nm})$ & $f_{\text {calcd }}$ & Transitions & CI expansion coefficients \\
\hline \multirow{6}{*}[\mathrm{Nb}_{6}\mathrm{O}_{19}]{$^{8-}$} & \multirow{6}{*}{294} & \multirow{6}{*}{282} & \multirow{6}{*}{0.2334} & $\mathrm{HOMO}-1$-> LUMO + 4 & 0.52512 \\
\hline & & & & HOMO -> LUMO + 5 & 0.24608 \\
\hline & & & & HOMO -> LUMO + 4 & 0.23348 \\
\hline & & & & $\mathrm{HOMO}-1$-> LUMO + 5 & -0.20839 \\
\hline & & & & HOMO -> LUMO + 3 & -0.11372 \\
\hline & & & & $\mathrm{HOMO}-1$-> LUMO + 1 & 0.10778 \\
\hline \multirow{4}{*}[\mathrm{Nb}_{10}\mathrm{O}_{28}]{$^{6-}$} & \multirow{4}{*}{310} & \multirow{4}{*}{283} & \multirow{4}{*}{0.0011} & HOMO - 3 -> LUMO & 0.61008 \\
\hline & & & & $\mathrm{HOMO}-4$-> LUMO + 3 & -0.25025 \\
\hline & & & & $\mathrm{HOMO}-6->\mathrm{LUMO}+1$ & 0.15390 \\
\hline & & & & $\mathrm{HOMO}-7$-> LUMO + 2 & -0.11470 \\
\hline \multirow{4}{*}[\mathrm{Ti}_{2}\mathrm{Nb}_{8}\mathrm{O}_{28}]{$^{8-}$} & \multirow{4}{*}{306} & \multirow{4}{*}{287} & \multirow{4}{*}{0.0259} & HOMO -> LUMO + 3 & 0.64577 \\
\hline & & & & $\mathrm{HOMO}-6->\mathrm{LUMO}+1$ & 0.14930 \\
\hline & & & & HOMO - 3 -> LUMO & -0.12456 \\
\hline & & & & HOMO -> LUMO + 9 & -0.10122 \\
\hline
\end{tabular}

6. The molecular orbitals of one-electron transitions contributing to actual transition for $\left[\mathrm{Nb}_{6} \mathrm{O}_{19}\right]^{8-}$.
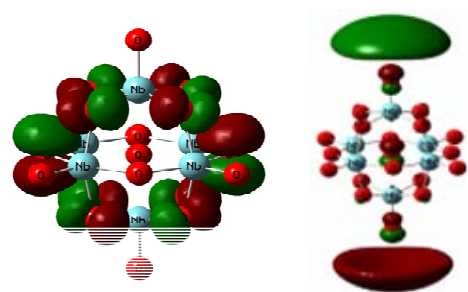

HOMO -

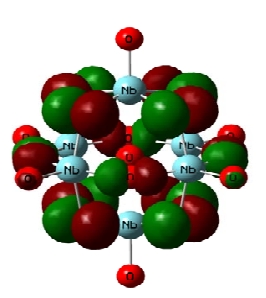

LUMO+4

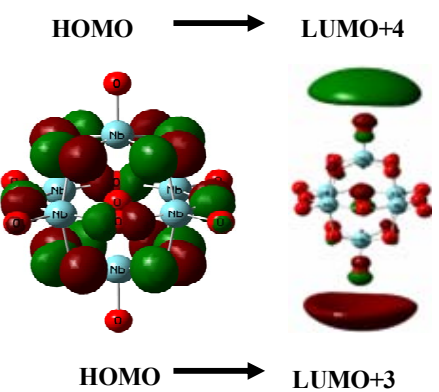

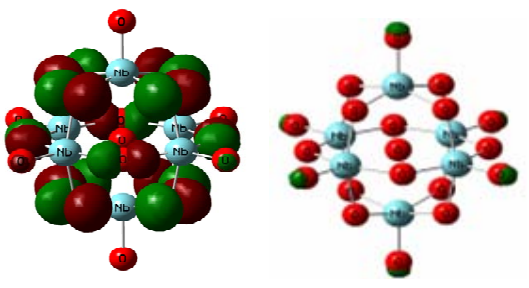

HOMO $\longrightarrow$ LUMO+5

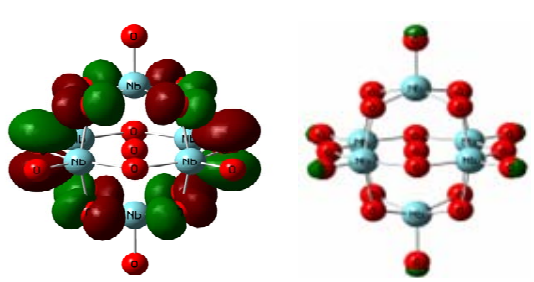

HOMO-1 $\longrightarrow$ LUMO +5
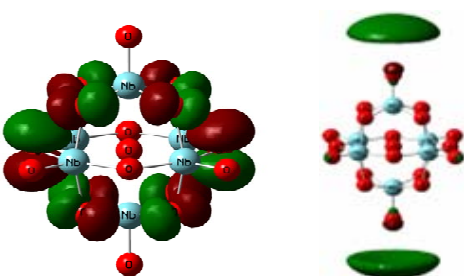

HOMO-1 $\longrightarrow$ LUMO+1

Figure S5. The molecular orbitals of one-electron transitions contributing to actual transition for $\left[\mathrm{Nb}_{6} \mathrm{O}_{19}\right]^{8-}$. These one-electron transitions contributes to the actual transition at aborption wavelength of $294 \mathrm{~nm}$. The transition from HOMO -1 to LUMO +4 contributes the largest component, in which the electron was transferred to $\eta$-O from $\mu_{2}-\mathrm{O}$. 
7. The molecular orbitals of one-electron transitions contributing to actual transition for $\left[\mathrm{Nb}_{10} \mathrm{O}_{28}\right]^{6-}$.

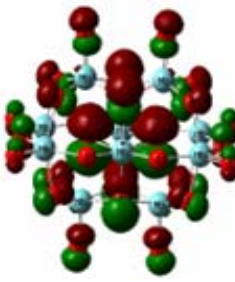

HOMO-3

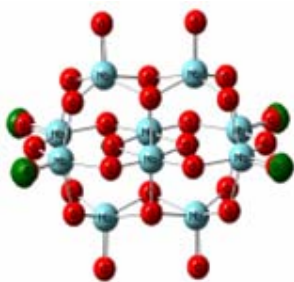

LUMO

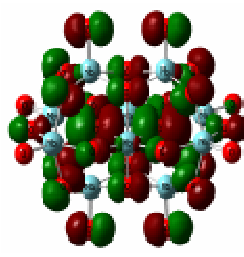

HOMO-3

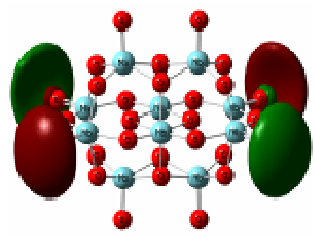

LUMO+3
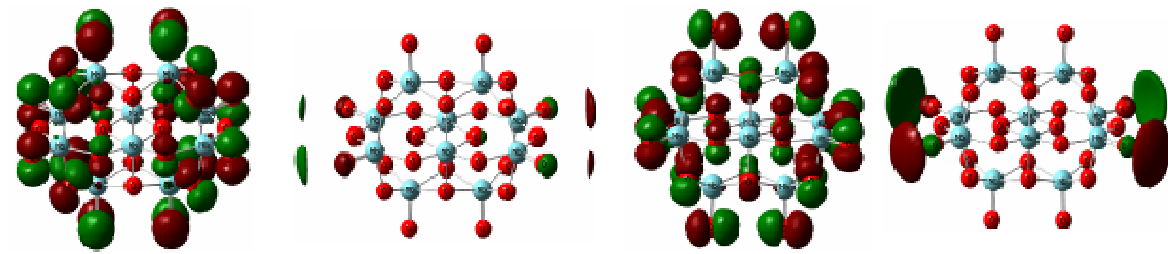

HOMO-6

LUMO+1

LUMO+2

Figure S6. The molecular orbitals of one-electron transitions contributing to actual transition for $\left[\mathrm{Nb}_{10} \mathrm{O}_{28}\right]^{6-}$. The one-electron transition from HOMO - 3 to LUMO contributes the largest component to actual transition at absorption wavelength of $310 \mathrm{~nm}$.

8. The molecular orbitals of one-electron transitions contributing to actual transition for $\left[\mathrm{Ti}_{2} \mathrm{Nb}_{8} \mathrm{O}_{28}\right]^{8-}$.
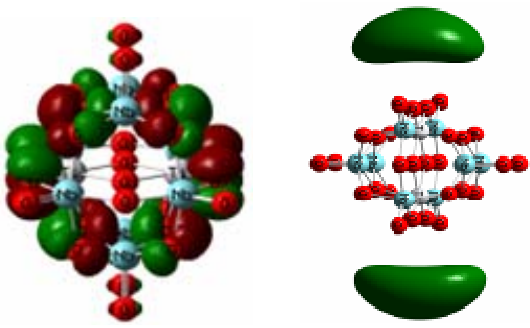

HOMO $\longrightarrow$ LUMO+3

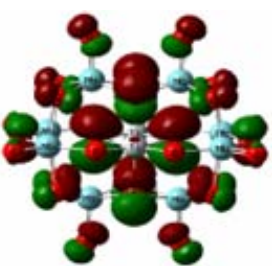

HOMO-3

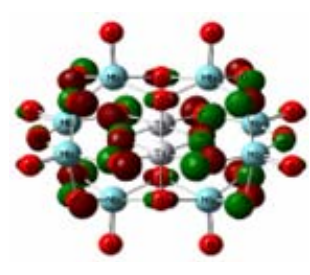

LUMO
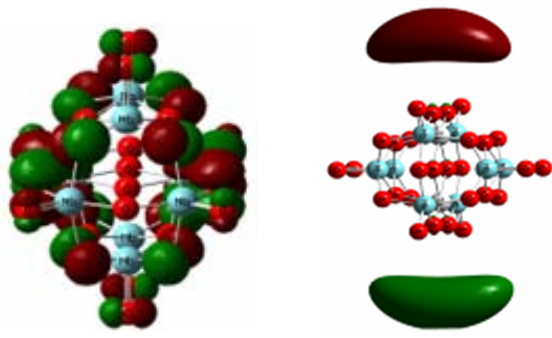

HOMO-6

LUMO+1
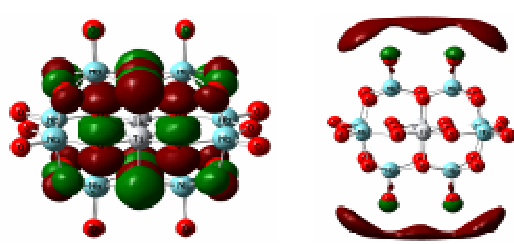

HOMO $\longrightarrow$ LUMO+9

Figure S7. The molecular orbitals of one-electron transitions contributing to actual transition for $\left[\mathrm{Ti}_{2} \mathrm{Nb}_{8} \mathrm{O}_{28}\right]^{8-}$. The one-electron transition from HOMO to LUMO +3 contributes the largest component to actual transition at absorption wavelength of $306 \mathrm{~nm}$. 